University of Nebraska - Lincoln

DigitalCommons@University of Nebraska - Lincoln

Faculty Papers and Publications in Animal

Science

Animal Science Department

2009

\title{
Cell Biology Symposium: The Role of MicroRNA in Cell Function
}

Andrea S. Cupp

University of Nebraska-Lincoln, acupp2@unl.edu

J. Matthews

University of Kentucky, Lexington

E. Huff-Lonergan

lowa State University

D. M. Spurlock

lowa State University

D. McLean

Washington State University, Pullman

Follow this and additional works at: https://digitalcommons.unl.edu/animalscifacpub

Part of the Animal Sciences Commons

Cupp, Andrea S.; Matthews, J.; Huff-Lonergan, E.; Spurlock, D. M.; and McLean, D., "Cell Biology Symposium: The Role of MicroRNA in Cell Function" (2009). Faculty Papers and Publications in Animal Science. 527.

https://digitalcommons.unl.edu/animalscifacpub/527

This Article is brought to you for free and open access by the Animal Science Department at DigitalCommons@University of Nebraska - Lincoln. It has been accepted for inclusion in Faculty Papers and Publications in Animal Science by an authorized administrator of DigitalCommons@University of Nebraska - Lincoln. 


\section{Cell Biology Symposium: The role of microRNA in cell function ${ }^{1}$}

\section{A. S. Cupp, ${ }^{* 2}$ J. Matthews, $†$ E. Huff-Lonergan, $\ddagger$ D. M. Spurlock, $\ddagger$ and D. McLean $\S$}

*Department of Animal Science, University of Nebraska, Lincoln 68583-0908; †Department of Animal Science, University of Kentucky, Lexington 40546-0215; †Department of Animal Science, Iowa State University, Ames 50011-3150; and §Department of Animal Science, Washington State University, Pullman 99164-6310

(0) 2009 American Society of Animal Science. All rights reserved.

J. Anim. Sci. 2009. 87(E. Suppl.):E19-E20

doi:10.2527/jas.2008-1552

A new symposium was introduced at the Centennial Meeting of the American Society of Animal Science (ASAS) meeting during the joint annual meeting of ASAS and the American Dairy Science Association in Indianapolis, Indiana, on July 8, 2008. The purpose of the Cell Biology Symposium is to bring scientists with cutting edge basic research on a particular theme to the ASAS meeting. In the future we hope to expand this symposium by including a poster session for ASAS participants and invited speakers to interact. This year the theme of the Cell Biology Symposium was "The role of microRNA in cell function." Four speakers delved into the basic function of microRNA, their role in hepatic cell function, regulation of muscle characteristics, and their role in female reproduction.

MicroRNA are defined as noncoding RNA, which are between 18 to 26 nucleotides long and which modulate gene expression posttranscriptionally by suppressing translation, causing degradation of particular messenger ribonucleic acid (mRNA) transcripts, or both (McDaneld, 2009). The manner in which microRNA cause reduced protein expression involves 1) degradation of mRNA sequences; 2) blocking translational initiation, elongation, or both, 3) and promoting translocation, storage, or both of mRNA into nontranslatable cellular depots (McDaneld, 2009). MicroRNA are highly conserved from nematodes to humans and are important in several biological processes, including cell fate, epigenetic changes, and apoptosis. Specifically, microRNA have been demonstrated to be important regulators of skeletal muscle, adipose, mammary and immune tissue, as well as embryonic development in domestic livestock species. Further research in humans and mice also demonstrated important roles for microRNA in reproduction and feed efficiency. Thus, research on microRNA

\footnotetext{
${ }^{1}$ Presented at the Cell Biology Symposium during the joint annual meeting of the American Society of Animal Science and American Dairy Science Association in Indianapolis, IN, July 7 to 11, 2008.

${ }^{2}$ Corresponding author: acupp@unlnotes.unl.edu

Received October 8, 2008.

Accepted October 10, 2008.
}

may divulge ways to regulate economically important traits in domestic livestock to increase profitability.

Because microRNA are involved in cell fate decisions, including cell proliferation, differentiation, and apoptotic pathways, alterations in their expression have been linked to progression of certain diseases, such as cancer. Exploiting the knowledge that unique microRNA signature profiles exist for cancerous tissue, Ghoshal et al. (2008) discussed how a specific disregulated microRNA may be involved in preneoplastic transformation of hepatocytes. Indeed, a significant amount of the current literature is focused on determining specific patterns or signatures of microRNA within tissues. These profiles may ultimately be useful tools to diagnose early stage diseases or disorders and possibly even the heritability of economically important agricultural traits, such as increased reproductive efficiency, muscle growth, and milk production.

MicroRNA can be ubiquitious or specifically expressed within certain tissues. In skeletal muscle, there are several specific highly expressed microRNA (e.g., mir1 and mir206) that can affect regulation of the myostatin gene, which is important in muscle development. In Texel sheep, the myostatin gene has a $\mathrm{G}$ to $\mathrm{A}$ transition in the $3^{\prime}$ untranslated region that creates a target site for mir1 and mir206, so when these microRNA bind, they inhibit the myostatin gene and cause muscular hypertrophy (Clop et al., 2006). Georges et al. (2006) demonstrated that polymorphisms that alter the $3^{\prime}$ untranslated region are common in humans and mice, and those authors speculated that these polymorphisms may be mediators of variation in phenotype and may also be important in regulating development of disorders and disease.

Targeted deletion of Dicer, the RNase III enzyme that processes precursor microRNA into mature singlestranded microRNA, within female reproductive tissues has implicated the importance of microRNA in a variety of developmental and functional processes. Reduced expression of Dicer in females results in infertility (Carletti and Christenson, 2009). Females without Dicer exhibited disrupted oviductal and uterine development, 
as well as reduced ovarian function, as evidenced by a decreased ovulation rate and presence of oocytes being trapped within the luteinized follicles (Hong et al., 2008). Similar to skeletal muscle tissue, specific microRNA appear to be upregulated in the granulosa cells of the periovulatory follicle after the LH surge (i.e., mir21, 132, and 212), the role of these microRNA are currently being investigated (Fiedler et al., 2008). Misregulation of microRNA may lead to anovulatory states causing infertility and increased culling rates in livestock. Thus, Carletti and Christenson (2009) proposed that understanding how microRNA may affect gene regulation may allow for manipulation of reproductive efficiency and reduction in the occurrence of reproductive disorders.

From the information presented at this first ASAS Cell Biology Symposium, microRNA appear to be important regulators of many biological systems that have the potential to greatly affect economically important traits in livestock. Further research in this area, specifically within livestock species, is critical to understanding how gene expression is silenced to allow for normal development, growth, and reproduction to occur. Furthermore, inappropriate regulation of microRNA may also lead to disorders or traits that decrease carcass quality or reproductive efficiency, thereby leading to reduced profitability.

\section{LITERATURE CITED}

Carletti, M., and L. K. Christenson. 2009. MicroRNA in the ovary and female reproductive tract. J. Anim. Sci. 87(E. Suppl.):E29E38.

Clop, A., F. Marcq, H. Takeda, D. Pirottin, X. Tordoir, B. Bibé, J. Bouix, F. Caiment, J. M. Elsen, F. Eychenne, C. Larzul, E. Laville, F. Meish, D. Milenkovic, J. Tobin, C. Charlier, and M. Georges. 2006. A mutation creating a potential illegitimate microRNA target site in the myostatin gene affects muscularity in sheep. Nat. Genet. 38:813-818.

Fiedler, S. D., M. Z. Carletti, X. Hong, and L. K. Christenson. 2008. Hormonal regulation of MicroRNA expression in periovulatory mouse mural granulosa cells. Biol. Reprod. doi:10.1095/biolreprod.108.069690 (Epub ahead of print).

Georges, M., A. Clop, F. Marcq, H. Takeda, D. Pirottin, S. Hiard, X. Tordoir, F. Caiment, F. Meish, B. Bibé, J. Bouix, J. M. Elsen, F. Eychenne, E. Laville, C. Larzul, D. Milenkovic, J. Tobin, and A. C. Charlier. 2006. Polymorphic microRNA-target interactions: A novel source of phenotypic variation. Cold Spring Harb. Symp. Quant. Biol. 71:343-350.

Ghoshal, K., J. Datta, and H. Kutay. 2008. Role of MicroRNAs in hepatocarcinogenesis in an animal model. J. Anim Sci. 86 (ESuppl. 2):E162. (Abstr.)

Hong, X., L. J. Luense, L. K. McGinnis, W. B. Nothnick, and L. K. Christenson. 2008. Dicer1 is essential for female fertility and normal development of the female reproductive system. Endocrinology doi:10.1210/en.2008-0294 (Epub ahead of print).

McDaneld, T. G. 2009. MicroRNA: Mechanism of gene regulation and application to livestock. J. Anim. Sci. 87(E. Suppl.):E21E28. 